\title{
P105: Efficacy of a virucidal surgical handrub
}

\author{
Y Kumashita,, P Mohan, M Mine, M Yamamoto \\ From 2nd International Conference on Prevention and Infection Control (ICPIC 2013) \\ Geneva, Switzerland. 25-28 June 2013
}

\section{Introduction}

Various alcohol (EtOH (ethanol), IPA (isopropanol) and PA (n-propanol)) and acid (Phosphoric acid and Lactic acid) combinations were evaluated to come up with a hand antiseptic formula that is virucidal (EN14476) and effective as a surgical handrub (EN12791) at a short contact time.

\section{Methods}

Screening tests using bacteriophage MS2 was performed, and combinations with good results were identified. These combinations were tested in accordance with EN14476 againt poliovirus, adenovirus, and feline calicivirus. The alcohol and acid combination with the best results was chosen, and an emollient was then added. This formulation was evaluated in accordance with several EN standards including EN12791. Skin irritation was also investigated.

\section{Results}

The mixture of EtOH (ethanol), PA (n-propanol) and Phosphoric acid exhibited the greatest efficacy among the combinations tested. When tested against EN standards for hand antiseptic, it was shown to meet EN14476 virucidal handrub and EN12791 surgical handrub requirements in relatively short contact times, less than 1 minute and 1 minute, respectively.

\section{Conclusion}

The handrub formulation containing EtOH, PA and Phosphoric acid exhibited excellent bactericidal and virucidal efficacy at a relatively short contact time and had lower skin irritation, suggesting that it is suitable for fast-acting hand disinfection.

\section{Disclosure of interest}

None declared.

Biochemical laboratory, Saraya CO. LTD., Osaka, Japan
Published: 20 June 2013

doi:10.1186/2047-2994-2-S1-P105

Cite this article as: Kumashita et al:: P105: Efficacy of a virucidal surgical handrub. Antimicrobial Resistance and Infection Control 2013 2(Suppl 1): P105.
Submit your next manuscript to BioMed Central and take full advantage of:

- Convenient online submission

- Thorough peer review

- No space constraints or color figure charges

- Immediate publication on acceptance

- Inclusion in PubMed, CAS, Scopus and Google Scholar

- Research which is freely available for redistribution
C Biomed Central

(c) 2013 Kumashita et al; licensee BioMed Central Ltd. This is an Open Access article distributed under the terms of the Creative Commons Attribution License (http://creativecommons.org/licenses/by/2.0), which permits unrestricted use, distribution, and reproduction in any medium, provided the original work is properly cited. 